\title{
BrIM 5D models and Lean Construction for planning work activities in reinforced concrete bridges
}

\author{
Modelos BrIM 5D y Lean Construction para planificar actividades de \\ obra en puentes de concreto reforzado \\ Modelos BrIM 5D e Lean Construction para planificar atividades de \\ obra em pontes de concreto reforçado
}

Fecha de recepción: 5 de mayo de 2016

Fecha de aceptación: 15 de julio de 2017

\author{
Omar Giovanny Sánchez-Rivera \\ José Alberto Galvis-Guerra* \\ Hernán Porras-Díaz" \\ Yerson Damián Ardila-Chacón ${ }^{* * *}$ \\ César Augusto Martínez-Martínez
}

\section{Abstract}

Integrating Building Information Modeling (BIM) and Lean Construction (LC) can improve the reinforced concrete bridging planning process, due to the possibility of managing the project information with BIM to obtain accurate input data that benefit the application of LC principles. The application of BIM to bridges is called Bridge Information Modeling (BrIM). In this paper, we study the feasibility of jointly apply BrIM technology and LC philosophy, instead of the individual use of BrIM models for planning reinforced concrete bridges. We used an investigative approach based on a case study, divided into two stages: in the first, we planned the case study with BrIM 3D models; and in the second, with BrIM 5D models and LC. The integration of BrIM and LC improve the results of the project planning stage by early detecting problems and constraints; this detection has the visualization and information management advantages provided by BIM, which along with the application of LC principles improve project planning, and encourage waste reduction.

Keywords: Bridge Information Modeling; Building Information Modeling; Lean Construction; Last Planner System.

\section{Resumen}

La integración de Building Information Modeling (BIM) y Lean Construction (LC) puede mejorar el proceso de planificación de puentes de concreto reforzado; esto se fundamenta en la posibilidad de gestionar la información del proyecto con BIM para obtener datos de entrada precisos que benefician la aplicación de los principios LC. La aplicación de BIM en puentes se denomina Bridge Information Modeling (BrIM). En el presente trabajo

* Ph. D. (c) Universidad Industrial de Santander (Bucaramanga-Santander, Colombia). omar.sanchez@correo.uis.edu.co.

** Universidad Industrial de Santander (Bucaramanga-Santander, Colombia). ORCID: 0000-0003-2695-0277.

*** Ph D. Universidad Industrial de Santander (Bucaramanga-Santander, Colombia). hporras@uis.edu.co.

**** Universidad Industrial de Santander (Bucaramanga-Santander, Colombia).

***** Universidad Industrial de Santander (Bucaramanga-Santander, Colombia). 
se estudia la viabilidad de aplicar conjuntamente la tecnología BrIM y la filosofía LC para planificar actividades de obra en puentes de concreto reforzado, frente al uso individual de modelos BrIM. Se utiliza un enfoque investigativo basado en un estudio de caso, dividido en dos etapas: en la primera se desarrolla la planificación del caso con modelos BrIM 3D, y en la segunda se realiza la planificación con modelos BrIM 5D y LC. Se observa que la integración de BrIM y LC mejora los resultados de la etapa de planificación de un proyecto mediante la detección temprana de problemas y restricciones; detección que es realizada con las ventajas de visualización y gestión de información proporcionadas por BIM, que con la aplicación de los principios LC mejora la planificación del proyecto y fomenta la reducción de desperdicios.

Palabras clave: Bridge Information Modeling; Building Information Modeling; Lean Construction; Sistema Último Planificador.

\section{Resumo}

A integração de Building Information Modeling (BIM) e Lean Construction (LC) pode melhorar o processo de planificação de pontes de concreto reforçado; isto fundamenta-se na possibilidade de gerenciar a informação do projeto com BIM para obter dados de entrada precisos que beneficiam a aplicação dos princípios LC. A aplicação de BIM em pontes denomina-se Bridge Information Modeling (BrIM). Neste trabalho estuda-se a viabilidade de aplicar conjuntamente a tecnologia BrIM e a filosofia LC para planificar atividades de obra em pontes de concreto reforçado, frente ao uso individual de modelos BrIM. Utiliza-se um enfoque de pesquisa baseado em um estudo de caso, dividido em duas etapas: na primeira desenvolve-se a planificação do caso com modelos BrIM 3D, e na segunda realiza-se a planificação com modelos BrIM 5D e LC. Observa-se que a integração de BrIM e LC melhora os resultados da etapa de planificação de um projeto mediante a detecção precoce de problemas e restrições; deteç̧ão que é realizada com as vantagens de visualização e gestão de informação proporcionadas por BIM, que com a aplicação dos princípios LC melhora a planificação do projeto e fomenta a redução de desperdícios.

Palavras chave: Bridge Information Modeling; Building Information Modeling; Lean Construction; Sistema Último Planificador. 


\section{INTRODUCTION}

Nowadays, the BIM technology approach has changed the stages of the life cycle of construction projects, from design to operation. BIM allows to elaborate models taking into account different dimensions, BIM 3D, 4D, and $\mathrm{nD}$. The 3D dimension is a representation of the project space, associated with information based on geometries, materials, and suppliers, among others. The 4D dimension is obtained by adding time, which allows to obtain a virtual simulation of the construction process. The fifth dimension is obtained by adding the cost, thus obtaining a BIM 5D model [1-5]. The application of BIM 5D technology to bridge modeling, known as Bridge Information Modeling or BrIM 5D, improves the three main concerns of the team planning a bridge construction: quality, work planning, and cost [6]. BrIM creates an environment of coordination and coherence between the information that is transmitted from the design stage to the maintenance and operation stage.

In bridge construction planning, BrIM 3D and BrIM 5D models allow to simulate the building process before starting the construction phase of the project, facilitating a more accurate estimate of the total project cost [1-4, 6-9]. Modeling and simulating the different stages of the construction process in BrIM 5D offers several advantages; the most significant are cost reduction in different phases of the project, storage and management of detailed information of the processes, estimation of construction quantities [2-7, 10], possibility of collaboration with professionals in different geographical locations, detection of inconsistencies in the project design [7], optimization of the work space [2-11], resource planning [2-7, 12], and the possibility of detecting failures and inconsistencies in planning, among others.

The Lean Construction (LC) philosophy is oriented toward administering the production in the construction sector [13-15]; its main objective is to reduce or eliminate activities that add no value to the project, and optimize activities that do; it is mainly focused on creating specific tools applied to the project execution process, and on producing a system that minimizes waste [12-16], understanding by residues everything that add no value to the activities necessary to complete the project.
The application of LC facilitates the creation of production systems that allow to optimize, reduce or eliminate flows and waste, with the goal of improving the execution times of the different construction processes [17, 18]. LC uses the scheduling system called Last Planner System (LPS), based on a cascade schedule, which focuses on reducing variability in the scheduling of project activities, and is divided into three schedules: general, intermediate, and weekly work [19-22]. The general schedule shows the whole set of activities that must be complete to finish the project; the intermediate schedule breaks down the general schedule into activities that have a high probability of being executed through a filtering process, which takes into account the necessary requirements (materials, equipment, tools, prerequisites, and others) to execute an activity; finally, the weekly schedule allows establishing a detailed work plan, executable week by week.

The implementation of BIM, along with the LC philosophy principles of waste reduction, is an effective combination for reducing uncertainty and wastes associated with the construction process. This combination is ideal for the planning stage of construction projects [23].

In this paper, we study the feasibility of using LC philosophy and BrIM 5D models in planning reinforced concrete bridges, compared to the planning method that only uses BrIM models. The benefits obtained from the implementation of BrIM 5D models and LC philosophy are shown in the planning process of construction projects.

\section{Methodology}

The application of LC principles and BrIM technology in planning work activities was based on the methodological framework proposed by Mao \& Zhang in their work "Construction process reengineering by integrating Lean Principles and computer simulation techniques" [24], where they proposed a reengineering of the constructive process using the LC philosophy (Fig. 1). 


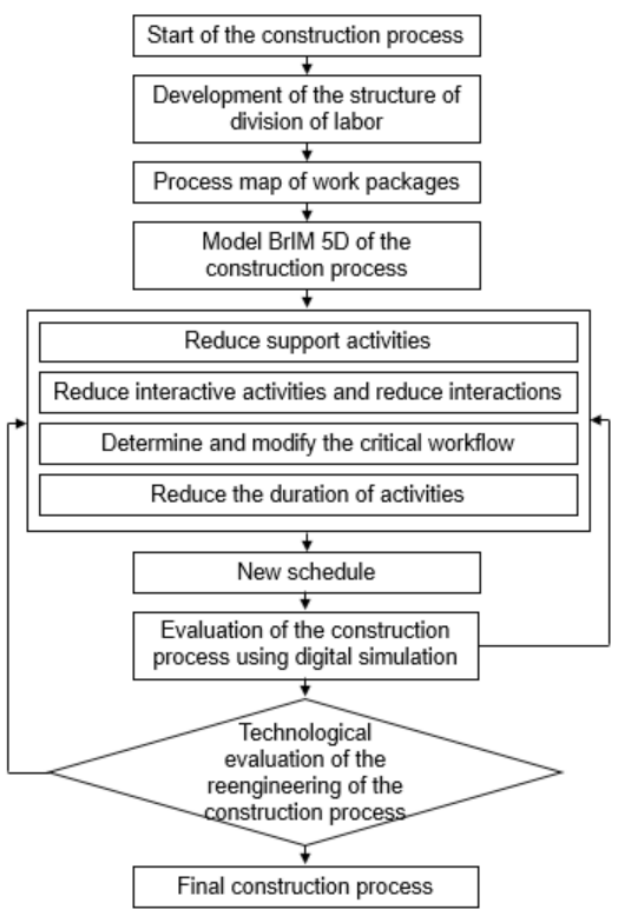

Fig. 1. Reengineering of the constructive process using the LC philosophy, based on [24].

We selected a research methodology based on a case study that consists of a reinforced concrete bridge of continuous beam typology, located in the city of Bucaramanga, to study the feasibility of applying BrIM 5D models and LC philosophy. The methodology was developed in two stages: first, we planned the case study using BrIM 3D models, and generated the budget and the schedule of the work activities from the BrIM 3D model information; and then, we planned the work activities using LC and BrIM 5D.

\section{A. Planning work activities with BrIM 3D technology}

The objective was to obtain the budget and the work schedule of the case study applying the BrIM 3D technology, without the Lean Construction waste reduction philosophy. We obtained the necessary results to compare with the methodology, and then, the Lean principles and the BrIM 5D model were linked.

\section{B. Reengineering the construction process based on BrIM and Lean Construction}

The objective was to obtain a schedule free of activities that add no value to the construction process, from the schedule obtained in stage one. This schedule allowed to study the feasibility of applying the BrIM 5D model and the LC philosophy for planning work activities in the construction of reinforced concrete bridges.

In the first part, we developed a work breakdown structure(WBS), which consisted in dividing the project into work packages in a logical and systematic way, in order to achieve an effective project management; the packages were divided into chapters, the chapters into sub-chapters, and so on, until specific activities could be programmed, budgeted, and controlled.

In the second part, we developed the flow of each construction process, in which the sequences and the links between the activities that compose the workflows were identified. The process map was a useful tool to study and understand the materials flow and to visualize the link between the activities.

In the third part, we built the BrIM 5D model of the construction process in Autodesk Navisworks software, from the case study design documents. In the elaboration of the model, we took into account the flows and links between the work activities identified in the process map.

In the fourth part, we applied the LC principles, which reduced supportive and interactive activities, thereby determining and modifying the critical workflow to reduce the duration of activities.

In the fifth part, after eliminating the activities that added no value, a new schedule of activities of the construction process was generated and subsequently evaluated by the BrIM 5D simulation. In a decision loop, the reengineering of the construction process activities was evaluated, taking into account the improvement expectations of the project's cost and time. Fig. 2 shows the reengineering process that was performed for the schedule obtained in the first stage of the research. 


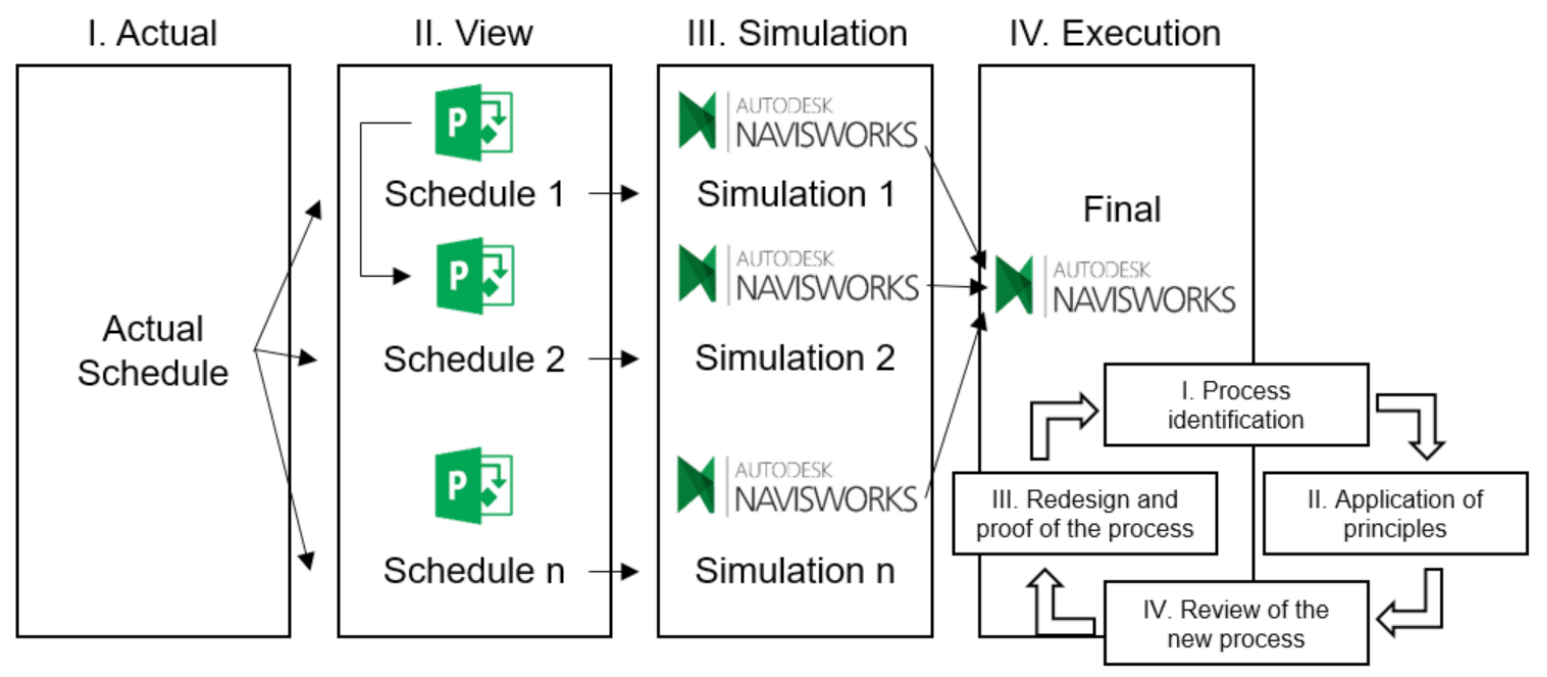

Fig. 2. Reduction of activities without value.

\section{RESULTS AND DISCUSSION}

\section{A. Stage 1: planning work activities using BrIM 3D}

The first result is the budget obtained from the budget estimation methodology using BIM 3D technology (Porras, Sánchez, Galvis) [25]. The second result consists in the work activities scheduled without using the LPS (Last Planner System) planning tool of the LC philosophy.

1) Construction budget with BrIM 3D: The process to elaborate the budget consisted in using the work quantities of each building element of the bridge, calculated automatically in the BrIM 3D model (Fig. 3 ), and multiplied by their unit price to obtain the cost of each construction activity for the case study. As a result of elaborating the construction budget (Table 1), the direct cost for the different construction activities was estimated, based on the required materials, equipment and labor.

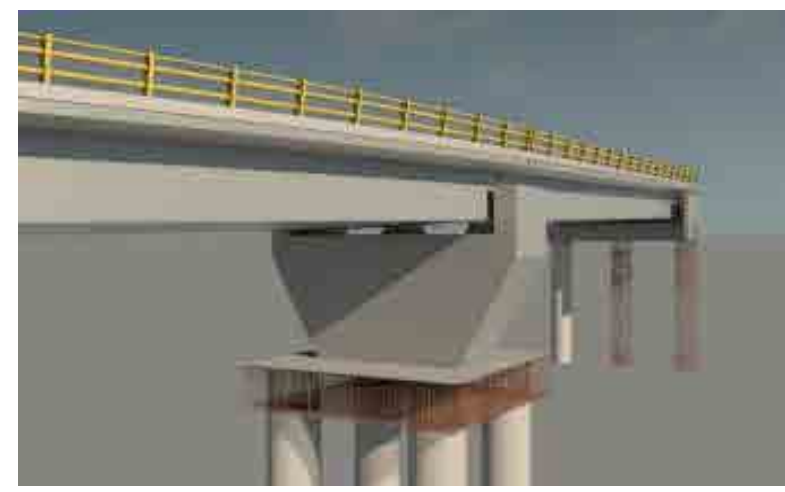

Fig. 3. BrIM 3D model of the case study. Developed in Autodesk Revit software. 


\section{TABLE 1}

Construction BUdGet OF THE CASE STUdy, IN COLOMBIAN PRICES

\begin{tabular}{|l|r|}
\hline \multicolumn{1}{|c|}{ Concept } & \multicolumn{1}{c|}{ Subtotal } \\
\hline Preliminaries & $\$ 94,760,299$ \\
\hline Excavations, fillers and drains & $\$ 15,912,818$ \\
\hline Concrete & $\$ 1,435,816,131$ \\
\hline Steel & $\$ 1,305,603,712$ \\
\hline Wrenches and anchor bolts & $\$ 32,906,618$ \\
\hline Anchor bolts & $\$ 2,210,293$ \\
\hline Town planning & $\$ 61,899,820$ \\
\hline Drainage & $\$ 636,192$ \\
\hline Signaling & $\$ 3,484,228$ \\
\hline Asphaltic folder & $\$ 13,232,861$ \\
\hline Direct cost & $\mathbf{\$ 2 , 9 6 6 , 4 6 2 , 9 7 2}$ \\
\hline
\end{tabular}

2) Work schedule with BrIM 3D: The schedule of work activities was obtained from the BrIM 3D model, which allowed to establish and differentiate each one of the constructive elements of the bridge. The work schedule was elaborated in Microsoft Project software.

\section{B. Stage 2: Planning with BrIM 5D and Lean Construction}

1) Development of the Work Breakdown Structure (WBS): The development of the WBS took into account three main packages: preliminary, construction, and operation. The present study mainly focused on the work package called 'construction'; this package has the foundation, structure, urbanism, and facilities chapters, which were considered to study the feasibility of applying the reengineering process based on the BrIM technology and the principles of the LC philosophy. Figure 4 shows the result of this stage.

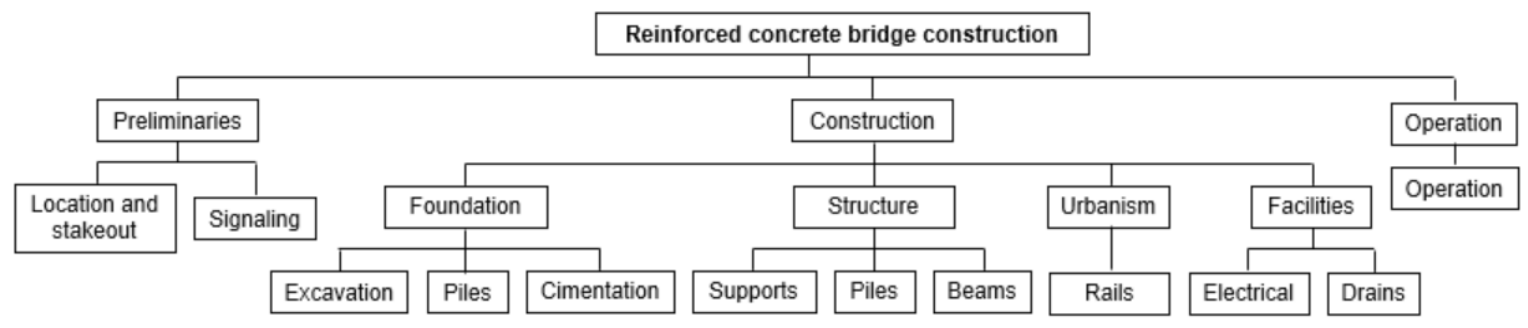

Fig. 4. Work breakdown structure (WBS).

2) Map of activities that add value: The map of value is one of the five principles of LC [26-27]; it represents all the activities that must be carried out for materializing the deliverables of the construction project, both activities that add value and those that add no value [28-30].

Continuous value mapping in construction projects is infrequent, due to the constant change in the production and to the little repetitive work that is carried out in a construction; however, it is important to examine the construction activities value flow and to determine the classification of the different wastes at the production stage [31-35]. In this research, the value flow mapping was developed to visualize the constructive process in a complete and understandable way, and thus, to determine the connections between the information and the material flow for a given package or workflow. Figure 5 shows the value flow map for the construction of the bridge piles. 


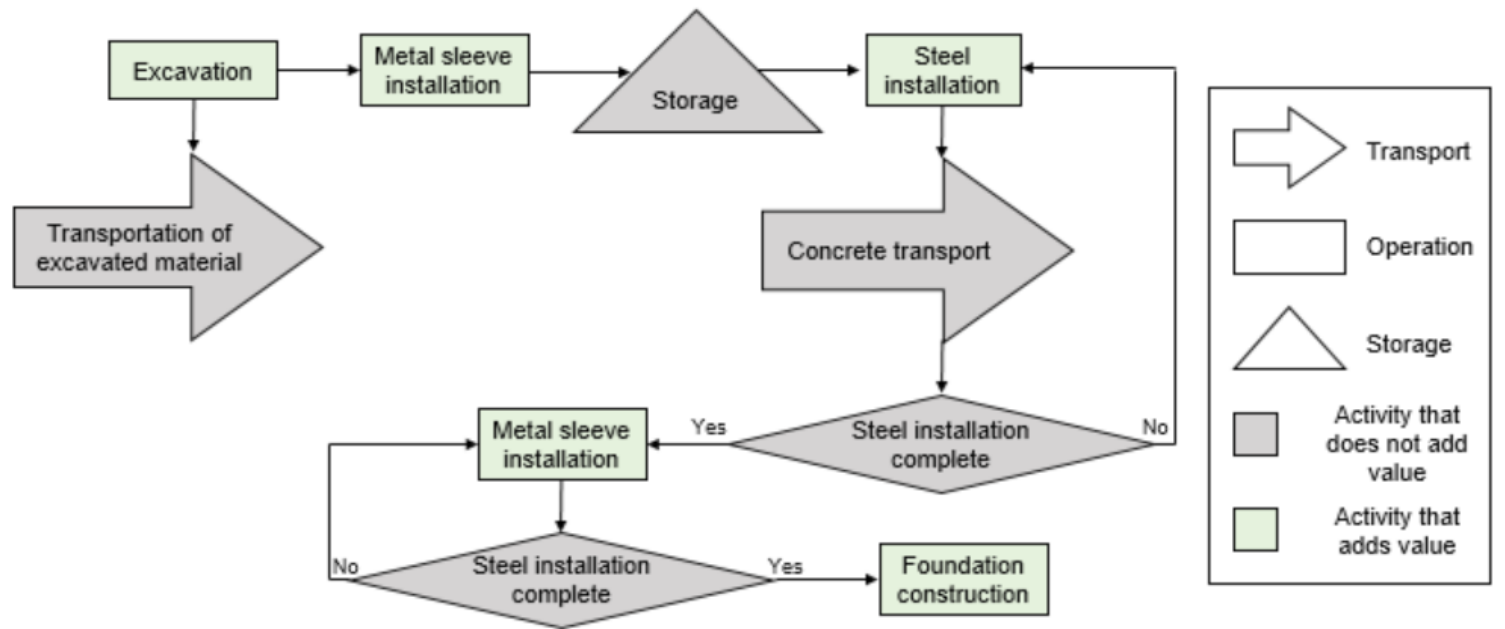

Fig. 5. Value flow map for pile construction.

3) BrIM 5D model of the construction process: Figure 6 shows five moments of the construction process simulation of the vehicular bridge under study (BrIM 5D model), made in the software Autodesk
Navisworks Manage. The simulation allowed to observe and study the virtual construction of the project, according to its schedule and its work budget.

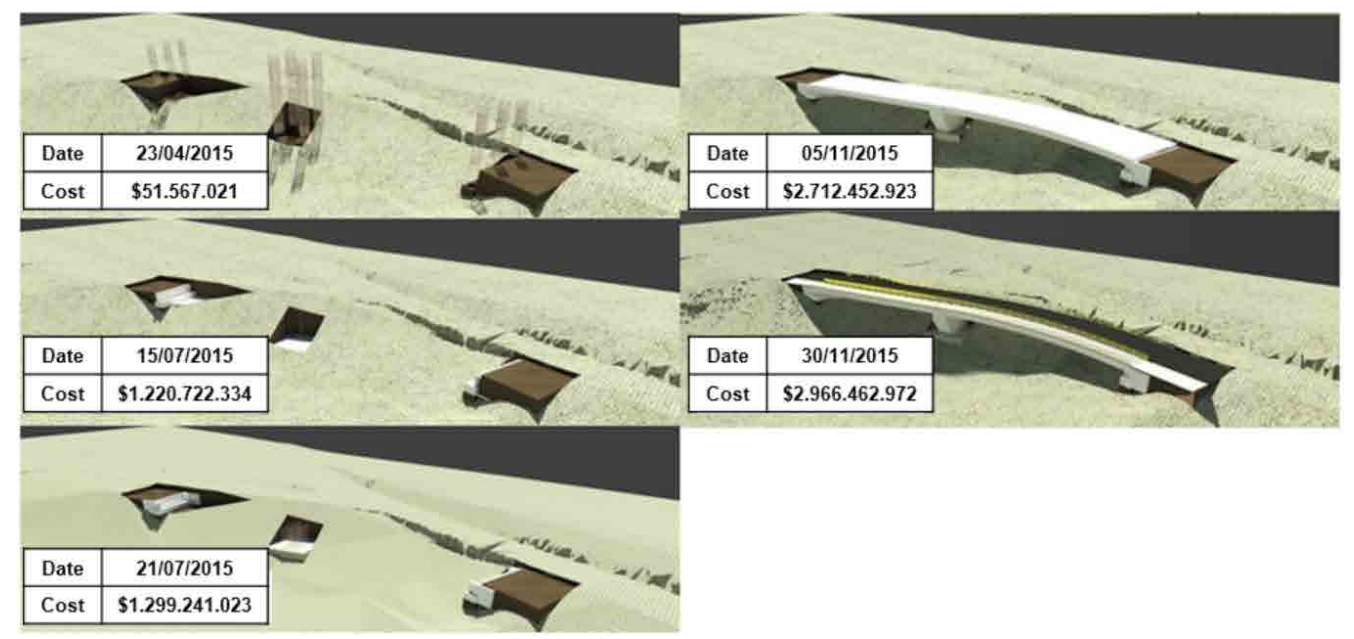

Fig. 6. BrIM Model 5D. Autodesk Navisworks Manage.

4) Applying Lean Construction principlesto planning: reducing activities that add no value: Activities that add no value are those that consume more resources (time, space, money, labor) than the estimates and the necessary for their execution, for example, emptying the concrete for the plates is an activity that generates value to the construction process, but the mixer delay time is an activity that takes away value.

From the value flow map (Fig. 5), we proceeded to reduce the time of those activities that add no value to the construction process. From the 'pile construction' work package, two types of activities that add no value were identified: support and interactive. The first are those that support and facilitate the execution of the main activities of the project, but do not contribute physically to the final product; interactive activities are those that interact with two or more activities and can be supportive or main. The delay of an interactive activity generates wastes in the construction process, because the previous activity must be completed in order to carry out the next activity in the schedule. For 
the case study, transport and production controls were identified as supporting activities, and steel assembly and concrete melting as interactive activities.

Once we identified the activities that add no value to the project, we recalculated the duration of the activities, and obtained a new work program, with which a new simulation was carried out in the BrIM 5D model; this with the goal of re-planning the construction process to obtain a better performance in the construction of the project.

\section{Improvement of the planning processes using BrIM and Lean Construction}

Using BrIM technology and applying the LPS planning system improved the development of the planning processes for bridge construction projects, taking into account that work quantities are obtained automatically using the model BrIM; therefore, the error induced by manual estimation is eliminated and the estimation of the total cost of the project (budget) is more efficient, due to the decrease of the uncertainty in the estimation of work quantities with BrIM. Alarcón and Pellicer [19] showed a significant difference between estimating the project direct costs using BIM models and estimating them using the model based on 2D drawings (.dwg format), obtaining a variation of $8.5 \%$ of the direct cost.

The use of BrIM allows the budget to be flexible to changes in the design, which are traditionally encountered in the planning stage; therefore, BrIM is a useful tool to improve the financial planning of bridge construction projects [36-37]. Table 2 shows the comparison between traditional planning with BrIM 3D models and the planning proposed in this research (BrIM 5D and LC).

\section{TABLE 2}

COMPARISON OF PLANNING METHODS

\begin{tabular}{|l|r|r|c|}
\hline \multicolumn{1}{|c|}{ Activities } & Cost with BrIM 3D & $\begin{array}{c}\text { Cost with BrIM 5D y } \\
\text { Lean }\end{array}$ & Variation \\
\hline Preliminaries & $\$ 94,760,299$ & $\$ 91,074,681$ & $-3.89 \%$ \\
\hline Excavations, fillers and drains & $\$ 15,912,818$ & $\$ 15,412,048$ & $-3.15 \%$ \\
\hline Concrete & $\$ 1,435,816,131$ & $\$ 1,375,950,840$ & $-4.17 \%$ \\
\hline Steel & $\$ 1,305,603,712$ & $\$ 1,234,211,452$ & $-5.47 \%$ \\
\hline Wrenches and anchor bolts & $\$ 32,906,618$ & $\$ 32,145,022$ & $-2.31 \%$ \\
\hline Anchor bolts & $\$ 2,210,293$ & $\$ 2,089,263$ & $-5.48 \%$ \\
\hline Town planning & $\$ 61,899,820$ & $\$ 56,328,836$ & $-9.00 \%$ \\
\hline Drainage & $\$ 636,192$ & $\$ 636,192$ & $0.00 \%$ \\
\hline Signaling & $\$ 3,484,228$ & $\$ 3,305,489$ & $-5.13 \%$ \\
\hline Asphaltic folder & $\mathbf{\$ 2 , 9 6 6 , 4 6 2 , 9 7 2}$ & $\mathbf{\$ 2 , 8 2 3 , 9 9 5 , 7 2 6}$ & $-\mathbf{- 4 . 8 0} \%$ \\
\hline Direct cost & & & \\
\hline
\end{tabular}

\section{Innovation in construction planning}

The planning stage of construction projects traditionally focuses on generating design documents (drawings, specifications, and construction details, among others) and evaluating the cost of each design alternative. We propose to add the simulation of the constructive processes with BrIM technologies in conjunction with the LC waste reduction principles, to strengthen the decision-making process in the planning phase by evaluating the construction processes in a virtual environment, and by analyzing in detail the workflow of the work activities. In this way, it is possible to make modifications in the planning phase instead of in the construction phase, when the bad decisions generate wastes.

The proposed planning methodology favors the reduction of the cycle times, which allows to simulate different alternatives that facilitate the relationships among resources, time, cost, and personnel. It is possible to reduce activities that add no value to the project, and thereby avoid work activities that consume more than the necessary resources [38]. 


\section{E. Benefits of applying BrIM technologies and} Lean Construction

Traditional planning obtains a program of extensive work based on assumptions, which only covers the activities that must be completed, and forgets to analyze whether they can really be achieved at the construction site. The application of BrIM and LC considers four levels of hierarchical planning, where as one descends in the hierarchy, the level of detail increases.

The planning system based on the LC principles and supported by BrIM manages to reduce losses by increasing the number of activities executed per week; therefore, it is possible to better control the uncertainty by overcoming obstacles such as turn planning into a system, performance measurement of the planning system implementation, and analysis and identification of errors in planning.

The integration of BrIM and LC showed the following benefits in the planning of construction projects:

- Increased reliability of the execution of construction activities

- Maintenance of a constant workflow

- Increase in the performance of work-on-site units

- Reduction of unforeseen events associated with lack of resources

- Minimal execution times of the projects

- Improvement in the work quality control

Table 3 shows a comparison between planning using individual BrIM 3D models and planning using both BrIM 5D and LC.

TABLe 3

COMPARISON OF PLANNING METHODS

\begin{tabular}{|c|c|c|}
\hline & Planning with BrIM 3D & $\begin{array}{c}\text { Planning with Lean } \\
\text { Construction + BrIM 5D }\end{array}$ \\
\hline Focus & Critical path & Managing variability \\
\hline Scope & Planning & $\begin{array}{c}\text { Planning, control and } \\
\text { measurement }\end{array}$ \\
\hline Mode of application & Unsystematic & Systematic \\
\hline Methodology & Dates control & Workflow management \\
\hline Commitment & Little & High \\
\hline Self-appraisal & No & Yes \\
\hline Improvement & Cost of activities & $\begin{array}{c}\text { Continuous improvement, } \\
\text { technology and reduction of } \\
\text { workflows }\end{array}$ \\
\hline Control & Cost of activities & Cost, time and quality \\
\hline Levels of detail & General & Discreet \\
\hline
\end{tabular}

The disadvantages encountered in the application of the system were the following:

- Learning the planning system makes implementation difficult

- There must be an efficient level of responsibility for the system to function

- Due to the high number of meetings, the system may fail due to lack of commitment

\section{F. Using BrIM 5D model and Lean Construction to} simulate the construction processes

- According to the LC theory, activities are classified into two categories: activities that add value and activities that add no value. Activities that add value are those that consume materials and contribute physically to the final project, whereas activities that add no value are those that generate "wastes". In the context of LC theory, the following loss-generating areas are identified: low quality 
in the final products, rework during construction, wastes due to excess of material, waste of time due to material transportation, waste of materials due to inventories and work under non-optimal conditions [30].

- Through the value flow map of the construction processes, it is possible to identify the types of activities that make up a project, and thus, it is possible to reduce or eliminate activities that do not generate value; subsequently, it is possible to simulate with BrIM 5D the new construction process without the activities that generate no value, thus the impact of eliminating these activities will be reflected before starting in the field the execution of the different construction processes.

- The simulation of the construction process is a useful resource for coordinating the interaction of the activities carried out by the working groups involved in the development of the construction phase [35]. Computer simulations can be used to validate and quantify the efficiency of a building process that is regenerated through Lean principles prior to the application. Mao \& Zhang [24] used the unified computer simulation with Lean principles in a road construction project, and concluded that the simulation was able to quantify the impact of reducing some activities that added no value to the activities in the construction of roads.

\section{Conclusions}

Reengineering a construction process applying the LC philosophy principles add value of great benefit to detect failures, which can be corrected and adjusted before starting the construction of the project instead of during the construction stage. In this way, it is possible to reduce losses due to poor planning, and increase the certainty and quality of the construction planning.

The use of BrIM models and LC philosophy in planning reinforced concrete bridge construction provides great benefits by improving accuracy and reducing uncertainty in the calculation of work quantities, taking into account that these quantities are automatically calculated according to the digitized construction elements in the BrIM model. This new approach to technology management allows to improve the planning processes, such as the estimation of both work quantities and budget, and the elaboration of work schedules.

The unified use of BrIM technology and LC philosophy improves the production process of construction projects. This new improvement is clearly a technological innovation in the planning of construction processes that achieves and allows the productivity and cost-benefit of the projects to be more effective and beneficial to the builders. In the bridge planning stage, the use of BrIM models facilitates the detection of LC problems or constraints, based on the visualization benefits provided by BIM, which improves the results of the LC application.

The application of the planning methodology proposed in this research allows to obtain benefits, such as increased reliability in the execution of work activities, maintenance of a constant workflow, increased work crew performance, decreased contingencies associated with the lack of resources, reduced execution times, and improved project control, among others. We can conclude that, from an application point of view, it is feasible to plan the construction process using Bridge Information Modeling (BrIM) technology and the reengineering process based on LC principles to obtain a highly feasible and executable construction process.

\section{REFERENCES}

[1] J. Gaitán, "Uso de la metodología BrIM (bridge information modeling) como herramienta para la planificación de la construcción de un puente de concreto en Colombia," Pontificia Universidad Javeriana, Bogotá, Colombia, 2013.

[2] W. C. Wang, S. W. Weng, S. H. Wang, et al., "Integrating building information models construction process simulations for project scheduling support," Automation in Construction, vol. 37, pp. 68-80, Jan. 2014. DOI: http://doi. org/10.1016/j.autcon.2013.10.009.

[3] C. Chen, "Applying BIM and simulation to schedule construction projects,” M.S. Thesis, National Chiao Tung University, Hsinchu, Taiwan, 2011.

[4] B. Koo, and M. Fisher, "Feasibility study of 4D CAD in comercial construction," Journal of Construction Engineering and Management, vol. 126 (4), pp. 251-260, Jul. 2000. DOI: http://doi.org/10.1061/ (ASCE)0733-9364(2000)126:4(251).

[5] A. Mahalingam, R. Kashyap, and C. Mahajan, "An evaluation of the applicability of 4D CAD on construction projects", Automation in Construction, 
vol. 19 (2), pp. 148-159, Mar. 2010. DOI: http://doi. org/10.1016/j.autcon.2009.11.015.

[6] M. Marzouk, and M. Hisham, "Implementing earned value management using bridge information modeling," Journal of Civil Engineering, vol. 18 (5), pp. 1302-1313, May. 2014. DOI: http://doi. org/10.1007/s12205-014-0455-9.

[7] E. Mikulakova, et al., "Knowledge-based schedule generation and evaluation," Advanced Engineering Informatics, vol. 24 (4), pp. 389-403, Nov. 2010. DOI: http://doi.org/10.1016/j.aei.2010.06.010.

[8] M. Marzouk, and M. Hisham, "Applications of building information modeling in cost estimation of infrastructure bridges," International Journal of 3-D Information Modeling, vol. 1 (2), pp. 17-29, Jun. 2012. DOI: http://doi.org/10.4018/ij3dim.2012040102.

[9] B. K. Al-Dosary, "Integrating 3D CAD and cost estimating at the conceptual design stage of bridge projects," M.S Thesis, University of Ottawa, Ottawa, Canada, 2015.

[10] Z. Mallasi, "Dynamic quantification and analysis of the construction workspace congestion utilising 4D visualization," Automation in Construction, vol. 15 (5), pp. 640-655, Sep. 2006. DOI: http://doi. org/10.1016/j.autcon.2005.08.005.

[11] H. J. Wang, J.P Zhang, K.W. Chau, et al., "4D dynamic management for construction planning and resource utilization," Automation in Construction, vol. 13 (5), pp. 575-589, Sep. 2004. DOI: http://doi. org/10.1016/j.autcon.2004.04.003.

[12] R. Al-Aomar, "Analysis of lean construction practices at Abu Dhabi construction industry," Lean Construction Journal, pp. 105-121, 2012.

[13] M. Tauriainen, P. Marttinen, B. Dave, and L. Koskela, "The effects of BIM and lean construction on design management practices," Procedia Engineering, vol. 164, pp. 567-574, 2016. DOI: http://doi. org/10.1016/j.proeng.2016.11.659.

[14] Y. Arayici, P. Coates, L. Koskela, M. Kagioglou, C. Usher, and K. O'Reilly, "Technology adoption in the BIM implementation for lean architectural practice," Automation in Construction, vol. 20 (2), pp. 189195, Mar. 2011. DOI: http://doi.org/10.1016/j. autcon.2010.09.016.

[15] L. Koskela, "Application of the new production philosophy to construction," CIFE Center for Integrated Facility Engineering - Stanford University, vol. 72, pp. 1-87, 1992.

[16] H. Porras, O. Sánchez, and J. Galvis, "Filosofía lean construction para la gestión de proyectos de construcción: una revisión actual," Revista Avances Investigación en Ingeniería, vol. 11 (1), pp. 10-32, Jun. 2014.

[17] T. Nath, M. Attarzadeh, L.K. Tiong, et al., "Productivity improvement of precast shop drawings generation through BIM-based process reengineering," Automation in Construction, vol. 54, pp. 54-68, Jun. 2015. DOI: http://doi.org/10.1016/j. autcon.2015.03.014.

[18] H. M. Shin, H. M. Lee, S. J. Oh, et al., "Analysis and design of reinforced concrete bridge column based on BIM," Procedia Engineering, vol. 14, pp. 2160-2163, 2011. DOI: http://doi.org/10.1016/j. proeng.2011.07.271.

[19] L. Alarcón, and E. Pellicer, "Un nuevo enfoque en la gestión: La construcción sin pérdidas," Revista de Obras Públicas, vol. 3, pp. 45-52, Feb. 2009.

[20] Y. Kim, and G. Ballard, "Management thinking in the earned value method system and the last planner system," Journal of Management in Engineering, vol. 26 (4), pp. 223-228, Oct. 2010. DOI: http://doi. org/10.1061/_ASCE_ME.1943-5479.0000026.

[21] G. Ballard, and G. Howell, "Lean project management," Building Research \& Information, vol. 31 (2), pp. 119-113, Jan. 2003. DOI: http://doi. org/10.1080/0961321031000083922.

[22] O. Seppanen, G. Ballard, and S. Personen, "The combination of last planner system and location based management system," Lean Construction Journal, pp. 43-54, 2010.

[23] B. McGuire, R. Atadero, C. Clevenger, et al., "Bridge information modeling for inspection and evaluation," Journal Bridge Engineering, vol. 21 (4), Apr. 2016. DOI: $\quad$ http://doi.org/10.1061/(ASCE)BE.19435592.0000850 .

[24] X. Mao, and X. Zhang, "Construction process reengineering by integrating lean principles and computer simulation techniques," Journal of construction Engineering and Management, vol. 134 (5), pp. 371-381, May. 2008. DOI: http://doi. org/10.1061/(ASCE)0733-9364(2008)134:5(371).

[25] H. Porras-Díaz, O. Sánchez, J. Galvis, et al., "Tecnologías "building information modeling" en la elaboración de presupuestos de construcción de estructuras en concreto reforzado," Entramado, vol. 11 (1), pp. 230-249, Jun. 2015. DOI: http://doi. org/10.18041/entramado.2015v11n1.21116.

[26] S. Senaratne, and A. Ekanayake, "Evaluation of application of lean principles to precast concrete bridge beam production process," Journal of Architectural Engineering, vol. 18 (2), pp. 94-106, Jun. 2012. DOI: http://doi.org/10.1061/(ASCE) AE.1943-5568.0000063.

[27] R. Sacks, L. Koskela, B. Dave, et al., "Interaction of lean and building information modeling in construction," Journal of Construction Engineering and Management, vol. 136 (9), pp. 968-980, Sep. 2010. DOI: http://doi.org/10.1061/(ASCE)CO.19437862.0000203.

[28] J. Won, J. Cheng, and G. Lee, "Quantification of construction waste prevented by BIM-based design validation. Case studies in South Korea," Waste Management, vol. 49, pp. 170-180, Mar. 2016. DOI: http://doi.org/10.1016/j.wasman.2015.12.026. 
[29] D. Bhargav, K. Sylvain, F. Kary, et al., "Opportunities for enhanced lean construction management using Internet of Things standards," Automation in construction, vol. 61, pp. 86-97, Jan. 2016. DOI: http://doi.org/10.1016/j.autcon.2015.10.009.

[30] P. Simonsson, "Industrial bridge construction with cast in place concrete-new production methods and lean construction philosophies," M.S Thesis, Lulea University of Technology, Lulea, Suecia, 2008.

[31] B. K. Al-Dosary, "Integrating 3D CAD and cost estimating at the conceptual design stage of bridge projects", M.S Thesis, University of Ottawa, Ottawa, Canada, 2015.

[32] M. Marzouk, M. Hisham, and K. Al-Gahtani, "Applications of bridge information modeling in bridges life cycle," Smart Structures and Systems, vol. 13 (3), pp. 407-418, Mar. 2014. DOI: http://doi. org/10.12989/sss.2014.13.3.407.

[33] T. Kivimäki, and R. Heikkilä, "Integrating 5D product modelling to On-site 3D surveying of bridges," in $26^{\text {th }}$ international symposium on automation and robotics in construction (ISARC), pp. 445-450. 2009.

[34] T. Kivimäki, and R. Heikkilä, "Bridge information modeling (BrIM) and model utilization at worksites in Finland," in $27^{\text {th }}$ international symposium on automation and robotics in construction (ISARC), pp. 505-513, 2010.

[35] M. Abaud, F. Shanti, and A. Pratama, "Simulation of construction operation: search for a practical and effective simulation system for construction practitioners," in Proceeding of the First Makassar International Conference on Civil Engineering, pp. 1311-1319, 2010.

[36] C. S. Shim, N. R. Yun, and H. H. Song, "Application of 3D bridge information modeling to design and construction of bridges," Procedia Engineering, vol. 14, pp. 95-99, 2011. DOI: http://doi.org/10.1016/j. proeng.2011.07.010.

[37] A. Nikakhtar, A. Hosseini, K. Wong, et al., "Application of lean construction principles to reduce construction process waste using computer simulation: a case study," Int. J. services and operations management, vol. 20 (4), pp. 461-480, 2015. DOI: http://doi.org/10.1504/ IJOM.2015.068528.

[38] S. A. Abbasian, A. Nikakhtar, and P. Ghoddousi, "Flow production of construction processes through implementing lean construction principles and simulation," International Journal of Engineering and Technology, vol. 4 (4), pp. 475-479, Aug. 2012. DOI: http://doi.org/10.7763/IJET.2012.V4.414. 